\title{
Gaining Education Character Based on Cultural Sundanese Values: The Innovation of Islamic Education Curriculum in Facing Era Society 5.0
}

\author{
Hisny Fajrussalam ${ }^{1}$, Agus Salim Mansyur ${ }^{2}$, Qiqi Yuliati Zaqiah ${ }^{2}$ \\ ${ }^{1}$ Universitas Pendidikan Indonesia, Indonesia \\ ${ }^{2}$ Universitas Islam Negeri Sunan Gunung Djati Bandung, Indonesia
}

Corresponding Author: Hisny Fajrussalam, $@$ hfajrussalam@gmail.com*

$$
\text { ABSTRACT }
$$

This research was motivated by moral and social crises that occur in Indonesian society, especially in West Java. It was predicted that the society is not ready to face this era if they analyse moral cases occur in West Java. Most people who adhere to this religion of Islam, have not

ARTICLE INFO

Article history:

Received

April 29, 2020

Revised

May 11, 2020

Accepted

June 07,2020 been able to fully realize the Islamic values in daily life. Ideally, education as a mediator in dealing with these cases presents a solution. Therefore, this article was to provide a basic inspiration regarding the innovation of the Islamic education curriculum based on the values of Sundanese cultural characters. This research uses library research's method by using inductive-deductive analysis as well as a comparison of literature and content analysis techniques. The result showed that the presence of an Islamic education curriculum based on cultural Sundanese character values could emerge a generation that upholds culture and Islam. Hence, it could make the next generation of a nation to have noble character.

Keywords: Sundanese Culture Value, Era Society 5.0, Curriculum, Islamic Education

How to cite Fajrussalam, H., Mansyur, A., \& Zaqiah, Q. (2020). Gaining Education Character Based on Cultural Sundanese Values: The Innovation of Islamic Education Curriculum in Facing Era of Society 5.0. Jurnal Iqra' : Kajian Ilmu Pendidikan, 5(1). 104-119. https://doi.org/10.25217/ji.v5i1.910

Journal Homepage http://journal.iaimnumetrolampung.ac.id/index.php/ji/

This is an open access article under the CC BY SA license https://creativecommons.org/licenses/by-sa/4.0/

Published by Institut Agama Islam Ma'arif NU (IAIMNU) Metro Lampung

\section{INTRODUCTION}

The term of character education, better known as nation and character building, is a term that has long been known. This vocabulary model first appeared in Indonesia since the Youth Pledge in 1928. This term then reemerged in 2010, precisely at the peak of the National Education Day, May $20^{\text {th }}, 2010$. Thus, the presence of this character education is to improve and reorganize the character of Indonesian society, which aims to make people have noble character.

The multidimensional crisis that nowadays occur in Indonesia is the backdrop of the emergence of character education. Indonesia, which is currently entering the Industrial Revolution Era 4.0, has some problems (Asikin, Z, 2019; Putra et al., 2018; Setiawan, 2019). We cannot deny that at this time in all countries, there are still social conflicts, the practices of violence, terrorisms, student fights, and even crimes that break the law (Akwen, G. T. et al., 2020; 
Jamal, J., \& Astuti, 2020). Data obtained from the Ministry of Communication and Information throughout 2019 indicates that there were still many complaints from Indonesian people regarding negative contents that occurred in Indonesia. The most negative complaints were related to the pornography with 244,738. Reports related to defamation and disquieting content were around 57,984 content and 53,455 content (Kominfo, 2020).

In addition to the foregoing, all complaints that were reported throughout 2019 consist of various elements. Some of them were related to SARA (racial intolerance), terrorism, and violence against children (Kominfo, 2020; Pusparisa, 2020). To further clarify, we can pay attention to the data mentioned in the following chart.

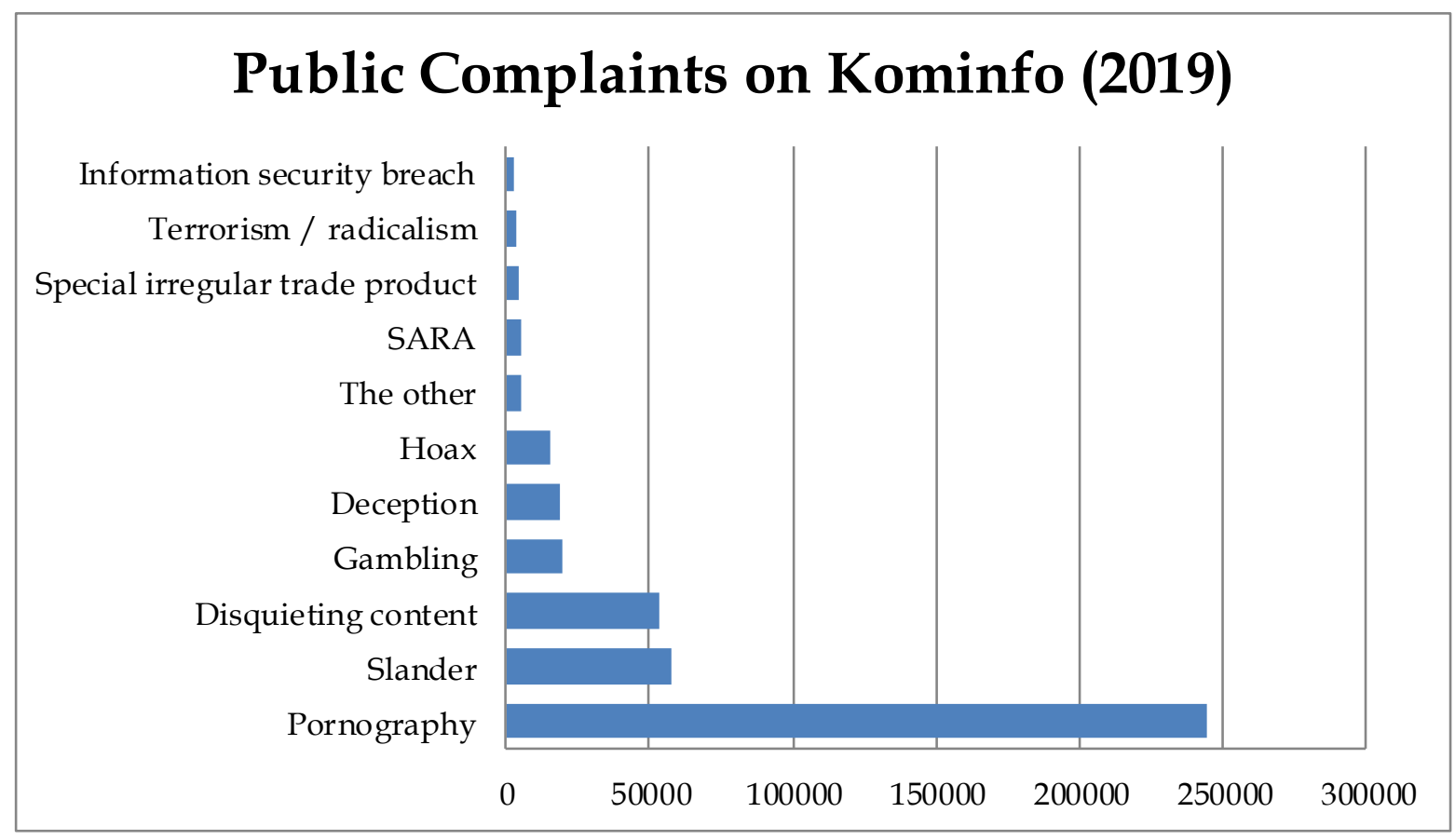

*) Separatism, extortion, information security breach, sector agencies, violence, drug abuse

Thus we know that Indonesian people, who are currently believed to be in the Industrial Revolution Era 4.0, are not yet mentally mature. How could the people of Indonesia successfully pass the 4.0 era and ready to face the new era known as the Era of Society 5.0 when the behavior of people has not changed Maryanti, et al., 2020) Meanwhile, education is a supporting in producing generations of good character and character. The practice of these two things can of course be seen from everyday life.

West Java, which is one of the most populous provinces in Indonesia, would be an exemplary province if only the people in Indonesia became a characterized society. Moreover, it is prone to moral decadence in the Province 
of West Java, as a province that has been a central point of technological development and globalization in the Industrial Revolution Era 4.0. Until now, the values of Sundanese cultural ethics that characterize the people of West Java began to be eroded by world developments. It is proven by the fact that in 2019 in West Java, the recorded social media abuse in the form of a hoax is 2,643 (Lestari, 2019). Therefore, it is necessary to re-establish cultural sundanese character to face the challenges of the times, one way is by through Islamic religious education, because the majority of the population of West Java adheres to Islam.

Various studies on innovations in Islamic religious education have been conducted by many researchers. First, a research conducted by Harahap, Nasution, \& Mardianto (2018) which focuses on studying information about innovations in Islamic religious education learning conducted in schools. Second, a research conducted by Hadi (2015), which concludes that religious values need to be cultivated in all school subjects. Third, the result of Rasyidi's research which emphasizes more on the curriculum by integrating a variety of intelligences including IQ (intelligent quotient), EQ (emotional quotient), CQ (creativity quotient) of and SQ (spiritual quotient) (Irsad, 2016). Fourth, Rasyidi produces findings that religious activities with Islamic nuances, such as Arabic club, al-Qur'an reading guidance, and local content with various studies of branches of science in Islam were considered important to be carried out in schools (Rasyidi, 2019). Fifth, the finding Sugiana (2019) which describes the development and implementation of the Islamic education curriculum.

From the above studies, it can be concluded that innovation in Islamic education is centered on instilling deep religious values. Meanwhile, there are not many kinds of research has been done on the innovation of the Islamic education curriculum based on cultural character values, or maybe there has been no research related to this before. This study uniquely presented of Improving Education Character Based on Sundanese Cultural Values. In nnovation of Islamic Education Curriculum in Facing Era of Society 5.0. Hence, the model of this research is important to be prioritized that the value of Islam and cultural character (Sundanese Value) can be integrated perfectly to produce outputs that uphold religion and culture.

On the other hand, Islamic values in Indonesia, especially in West Java, have not been implemented in people's daily lives. It is analysed from the fact that the crisis of morality in West Java can be encountered every day and Islamic religious education is one of the important elements to develop a good character. Based on that phenomenon, this article intends to investigate character education as an element of the Islamic education curriculum in preparing society for a new era through education.

\section{METHODS}

This research uses a qualitative approach. The research model used is library research using inductive-deductive analysis as well as a comparison of literature (O'Dwyer \& Bernauer, 2013; Moser \& Korstjens, 2018). The type of 
data used is secondary data with research sources in the form of documents in the form of books and journal articles on curriculum innovation, Sundanese cultural character values, and character education. The techniques used in this study are data compilation, data analysis, and conclusions, while the data analysis technique uses a content analysis technique.

While the analysis method and interpretation of the data which was used by researchers refer to the steps of analysis raised by Creswell (2016), First, Processing and preparing data for review; Second, reading the entire data; Third, Starting to code all research data; Fourth, describing the category and the theme settings to be analyzed; Fifth, Presenting qualitative narrative reports, and Sixth, Making interpretations in qualitative research

\section{RESULT AND DISCUSSION \\ Curriculum Innovation}

Innovation is closely related to a change, but not every change is innovation. Change is a necessity, even philosophers said that there is nothing eternal in this world except change. Hence, the humanity cannot avoid any change. In the context of a dynamic world of education, change is necessary, because without change, the world of education will be left behind and the next generation of the nation will not be able to pursue progress so that there is only the potential for disaster and misfortune (Prastyawan, 2011). Meanwhile, innovation is an idea, practice, or object that is considered new by someone or another adopter group (Rogers, 1983).

Curriculum is one important aspect in the educational context. In a simple explanation, a curriculum can be interpreted as a collection of lessons that will be taught to students, which is ended by providing an assessment in the form of learning outcomes' achievement within a certain period. However, the curriculum is often used as a scapegoat to some failure in education. It is stated that the failure is caused by the frequency of curriculum changes that are not measurable. It has to be understood that the curriculum must be dynamic and adaptive following changes in society, both the business and work world. To understand curriculum changes, we have to understand three main ideas, namely: a) the change plan is always good; b) it must be separated between change and stability; and c) if the change plan has been adopted, it is necessary to make improvements to these changes (Mahmud, 2013).

\section{Education Character}

Today discourses on character have entered a new phase in the world literature of education. Countries in the world have begun to focus on preparing a quality generation through character education. This education model is not only intended for the individual interest as a citizen but also for all citizens in general. Character education can be interpreted as a deliberate effort of all dimensions of social life to optimally help the formation of character (Dalmeri, 2014). 
The word "character" came from French and Latin, which means sign and distinctive quality. It's also derived from Greek, charassein, which is defined as giving meaning or carving (Sulasmono, Ekosiswoyo, \& Widodo, 2017). Terminologically, character is an attitude that can respond to situations in a morally good way (Marshall, Caldwell \& Foster, 2011). In other literature, it is said that character education is a conscious effort to help someone so that he can understand, pay attention, and carry out the core of ethical values. Besides, Lickona mentioned that character education is a deliberate effort to objectively realize the good quality of humanity, not only good for individuals, but also society in global (Lickona, 2004). Thomas Lickona said that the character has three parts that cannot be separated from each other, namely moral knowledge, moral feelings, and moral action Marshall, Caldwell \& Foster, 2011). Hence, good character is an activity series that comes from the knowledge that is concerning goodness, then it raises an individual's intention to do the good which is finally implemented by doing a good thing. Zubaedi stated that character education is comprehensive and integrated. Character education that relies on just one strategy is not sufficient to make students morally smart. Therefore, we need several approaches as proposed by Kirschenbaum called the comprehensive approach. The term "comprehensive approach" in character education includes the following aspects: content, methods, processes, subjects, and evaluation (Zubaedi, 2015). It is specifically stated that the contents or materials of character education can be categorized into three moral values, namely moral for God, moral for others, and moral for the environment (Nurul, 2010).

Davidson, Lickona, \& Khmelkov (2014) explained that there is a role for characters in all achievements in schools, both curricular or non-curricular activities. The research was conducted in 24 of the best schools in the US. The findings show that the character consists of two major parts, namely the performance character and moral character. The performance character involves all the values that enable people to actualize their potential in the classroom or workplace. In addition, a study conducted by Jeynes (2019) about the relationship between character education and school achievement in several elementary schools in California concluded that schools that teach character education seriously tend to have high academic achievement.

\section{Core Ethical Values: Character Education Based on Cultural Sundanese Character Values}

The culture of a nation is an identity that must be studied and well defended. Therefore, in order to maintain it, intelligence is needed to interpret a cultural meaning. Culture means innovation and change, and culture is the source of change itself (Sulhan, 2018). Culture-based character education is an education that teaches to be always close and ready to face the real situation (Istiawati, 2016). Culture-based character education defines culture as something that must be learned, nurtured, and continued to the next generation. 
The functional relationship between education and culture contains two meanings; the first is reflective which means the current picture of culture, and the second is progressive, an education that's leading to renewal and bringing culture toward advanced civilization. Reflective and progressive are two things where the educational process is an individual effort that leads to innovative and dynamic efforts in order to be better in facing the times change (Sulhan, 2018). Therefore, it can be said that character education is the end of an education process.

Meanwhile, culture is interpreted as an idea of life. Such thinking is based on clear contemplation and pure thought that contains positive things. Culture can also be translated as the work of the mind, deep feelings, and character (Sulasmono et al., 2017). Cultural wisdom is closely related to ethnic terms. Ethnic groups are people who are bound by awareness and identity of "cultural unity", where the language element is their specific characteristic (Ida, 2014). So that, Sundanese cultural wisdom can be defined as a social and cultural condition which contains cultural-based character values that are respectful and adaptive to the surrounding nature and are arranged in a steadily in the order of traditions in a society. Although often considered obsolete, the values they teach and practice are still the best way to preserve the environment in post-modern times (Indrawardana, 2013). Sundanese society as a community that holds fast to the Sundanese culture is not a group of people that connects individuals and individuals to the community, but a unity that is closely attached by the norms of life because of history, tradition, and religion. The family, as the smallest unit, has a role as a strap among others to be drawn to a wider area, namely villages, countries, even the world.

The core values of Sundanese characters are welfare, health, environmental care, moderate, hard work, discipline, politeness, honesty, upholding the truth, mutual assistance, social solidarity, positive thinking, mature consideration, education, gender management, and preservation and cultural creativity. These values are reflected in the view of life, oral traditions, proverbs, and pro-social behavior that grows and develops in Sundanese society. More clearly, Fajrussalam \& Hasanah (2018) has described the flow of these values in the following figure. 
Figure 1. The Flow of Sundanese Character Values

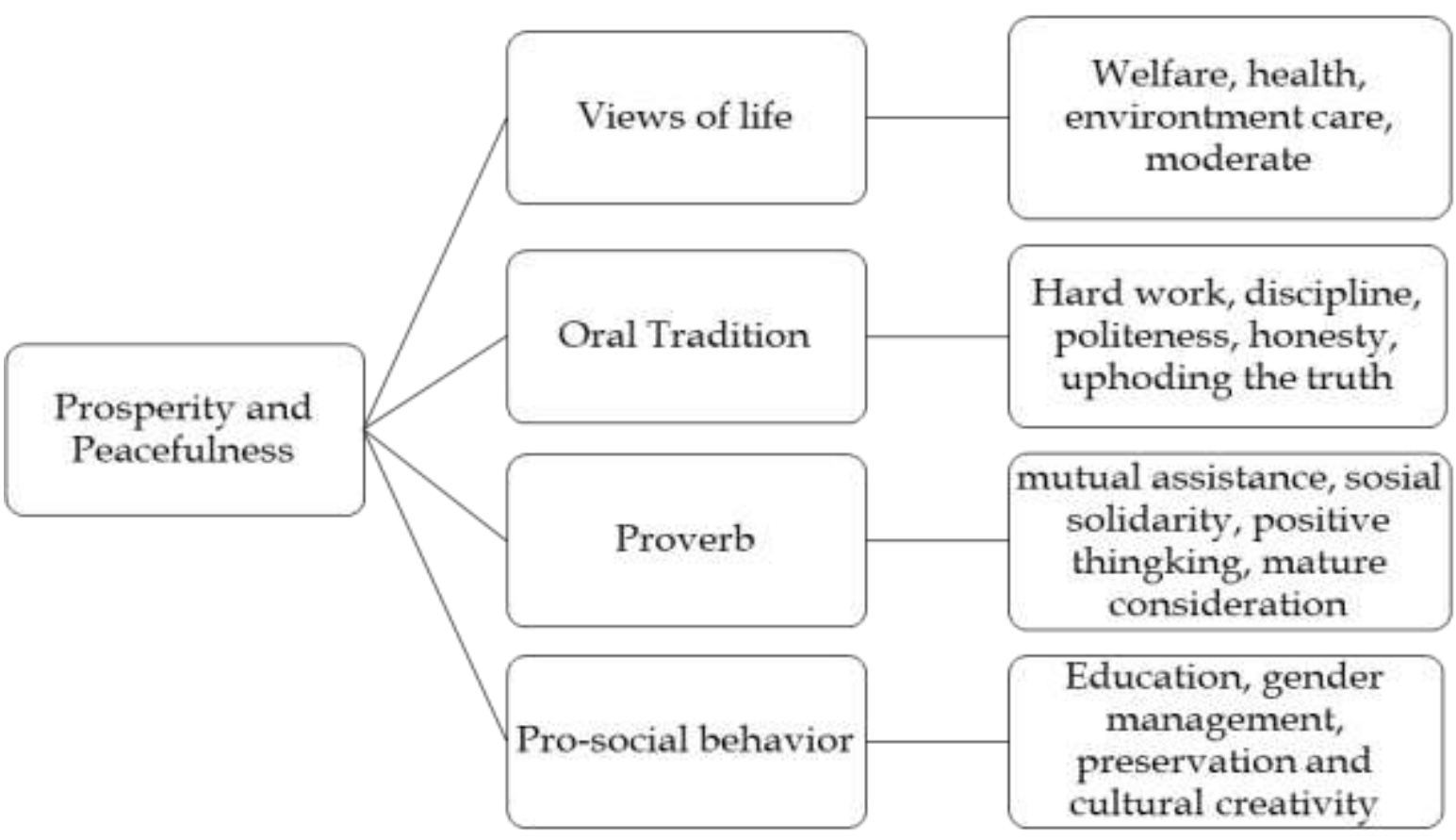

The Urgency of Innovation of Islamic Education Curriculum Based on Sundanese Culture Values

Education has an important role in achieving the success of development and civilization in a nation. Countries in the world can be categorized as advanced countries because of their superior education system. For example, the United States of America is no doubt about the economic and military achievements that can be emulated by other countries in the world. However, the quality of education in the United States still cannot be compared with other countries. Therefore, education is a deriving system that determines the civilization and progress of a nation.

On the other hand, the quality of education is largely determined by curriculum design. The curriculum currently in use, namely the Curriculum of 2013, has not been able to eliminate deviant behavior in society, especially in nowadays where Indonesia is on suffering from the technological fever that causes any content to be freely accessed. Therefore, it is necessary to strengthen the characters that are integrated into the curriculum. Even though there is already a character content in the 2013 curriculum, but the curriculum innovation based on Sundanese character values is considered important to refresh the previous curriculum in a better direction. Character-based curriculum innovation is an urgent need due to 3 main things (Mansyur, 2007). First, success is determined by character. According to research conducted at Harvard University, a person's success is not purely determined by his/her 
intellectual intelligence, knowledge and technical abilities, but his/her ability to manage himself/herself, others and his/her environment, actually takes a greater role in determining the success (Mansyur, 2007).

Second, character is formed from education and the environment. In interacting with the environment, learners will instinctively try to develop a correct understanding of how the world and humans from all aspects of life exist on earth. That is, the good character of the learners will grow in line with the educational environment that also has good character.

Third, Indonesia needs strong human resources, because naturally it's needed reliable human resources to support national development. Here education plays its role as mandated by Law No. 20 of 2003 concerning the National Education System which states that national education functions to develop capabilities and shape the character and civilization of a dignified nation in order to develop the life of the nation.

\section{Innovation of Islamic Education Curriculum Based on Cultural Sundanese of Character Values}

The curriculum of Islamic education based on cultural Sundanese character values aims to instill, civilize, and empower cultural Sundanese character values to students, both as individuals and the community. The purpose of this curriculum is to create a generation that serves God Almighty because Sundanese cultural character values are relevant to the essence of the Qur'an. The core ethical values of Sundanese culture are welfare, health, environmental care, moderate, hard work, discipline, politeness, honesty, upholding the truth, mutual assistance, positive thinking, mature consideration, education, gender management, preservation and cultural creativity (Fajrussalam \& Hasanah, 2018).

The purposes of implementing Islamic education curriculum based on Sundanese cultural character values are first, to integrate Islamic values and Sundanese cultural character values; second, to develop students' potential in conscience perspective as humans who have cultural character values; third, to develop good attitudes and behaviors that are in line with national culture; fourth, instill a spirit of discipline and responsibility as the next generation of the nation; fifth, to develop an attitude of caring for the environment as part of the teachings of Islam.

Meanwhile, regarding the characteristics of the Islamic education curriculum based on Sundanese cultural character values, this curriculum has four characteristics by adopting the concept of character education from F.W. Foerster (Mansyur, 2007). The first is the emphasis on every action that is based on normative values, so that the basic character building of students is knowledge, understanding, and practice of good and bad ethics. The second is the effort to build courage and self-confidence (coherence). The third is the practice of rules and norms that are believed by students so that they become values in themselves (autonomy). The last is the effort to build persistence and loyalty. 
The curriculum of Islamic education based on Sundanese character values is expected to be a solution regarding the existing educational problems in West Java. The core ethical values of Sundanese characters can be included in the curriculum of Islamic education which is finally implemented in the learning and habituation process in schools. More clearly, we can see the following figure.

Figure 2. The Implementation of Core ethical Values Based on Cultural Sundanese Values in Islamic Education Curriculum

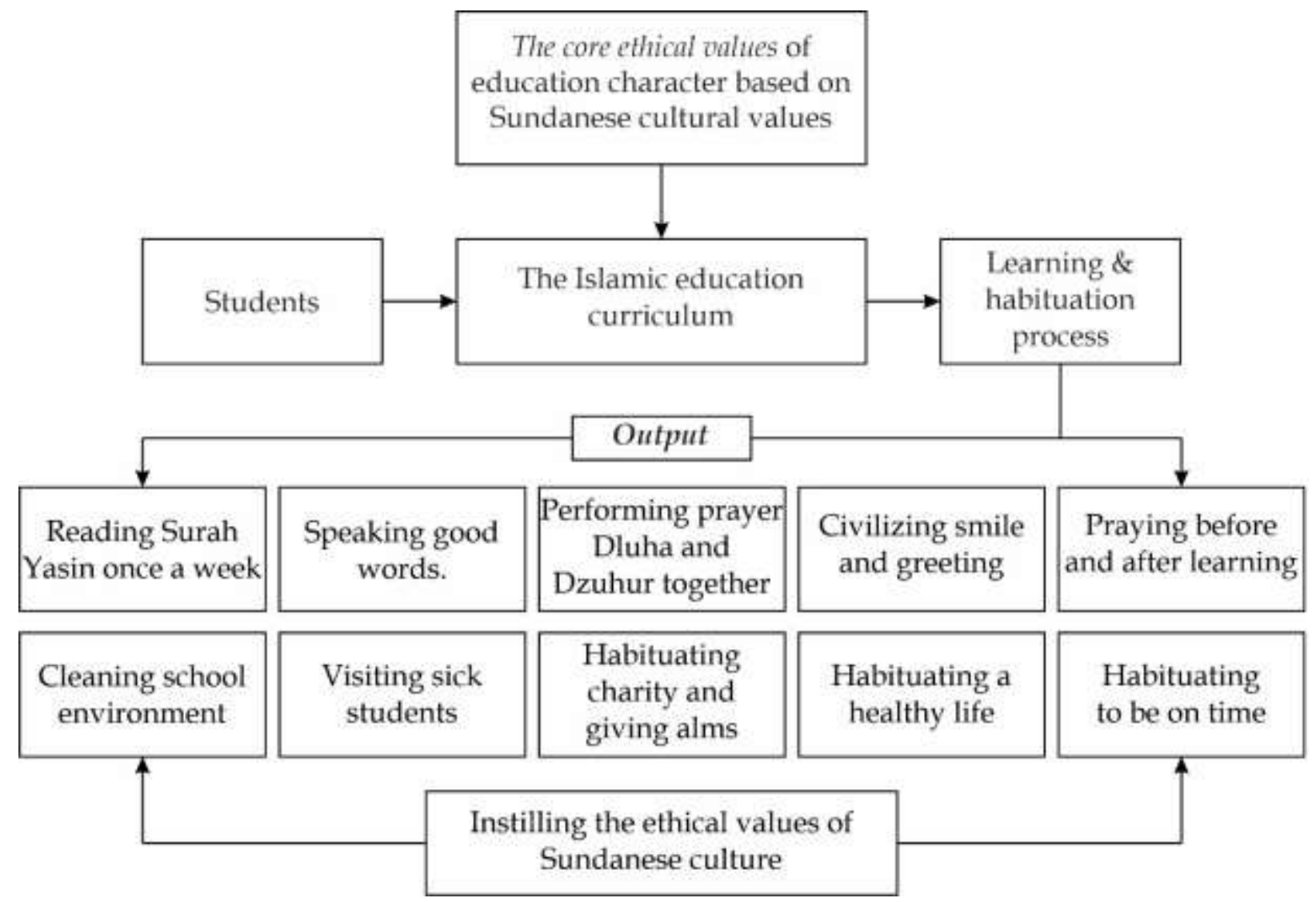

Figure 2. shows that the current Islamic education curriculum can be integrated with core ethical values based on Sundanese cultural character values. The content of core ethical values can be incorporated into various subjects of Islamic education. The main result of the study indicates that the implementation of core ethical values based on Sundanese cultural character values in the Islamic education curriculum begins with a learning and habituation process that functions as an investment of Sundanese character values to produce a quality generation. The formation of these values cannot be performed only once or twice, but continuously.

The learning and habituation process which is performed firstly is reading the Surah Yasin once a week. The activity is an interpretation of the value of education as one of the core ethical values based on Sundanese cultural 
character values. As an educational process, reading the Surat Yasin once a week will also foster students' religious attitudes (Pratikno, 2016). Religious attitudes are behaviors that show adherence to the teachings of their religion, tolerance, and coexistence in harmony with other religions. Tolerance also aims to create a conducive atmosphere and a feeling of peace in religious life. This is of course in line with the mission of the Islamic religion based on rahmatan lil 'alamin (the mercy to the world), so that peace in religious life can be achieved (Asriati, 2012). The Second is speaking good words (well-spoken). Good wordspeaking habits in Sundanese cultural values are included in the category of politeness. A good attitude of speech can be seen from its principles, namely not speaking knowledgeably and not arguing to defend what is not worth defending (Tajuddin, 2015). Humans are creatures that not only have advantages, but also disadvantages. Therefore, the behavior that reflects the sense of self knows best of everything is a mistake, and that person has the potential to become arrogant, make him selfish, and tends to underestimate others (Habibah, 2015). The third is performing Shalat Dhuha and Dzuhur. This activity aims to educate students to always uphold the truth as a value of Sundanese cultural ethics. The implementation of the prayer is an attitude of realizing the truth that God exists and humans are instructed to perform prayer. Starting from this, with learning and habituation of Dhuha and Dhuhur prayers in congregation, it is hoped that the attitude of upholding the truth can be formed in students, not only in the context of worship but also in the social context. The fourth, the culture of smiling and greetings. This culture is a habit when communicating and socializing with others. This can be seen from historical facts when long ago the Indonesian people smiled at each other, and greetings when they met with the colonizing nation. However, the culture of smiling and greeting culture lately began to be abandoned in line with the times and modernization that prefers eastern culture. The result shows that the culture of a smile and greeting can foster discipline, friendship, peace, and character in the range of $85 \%$ (Pratiwi, 2017). Hence, the culture of smiling and greetings should be revived as a community identity, especially in West Java. The fifth is praying before and after the learning process. This practice of praying is an Islamic work culture in actualizing the potentials exist in a person, those are the faith, thought, remembrance (dzikir), and the knowledge possessed to obtain the happiness of life. Islamic work culture in the practice of praying before and after learning is undeniably starting to disappear. The habit of praying before going home led by student leaders is now rarely seen in schools whereas habits like this can foster a sense of students' discipline. Furthermore, research conducted by Rahmi (2016) shows that civilizing praying before and after learning can improve the quality of students' learning outcomes. The sixth is habituation to come on time. There is a saying that time is money. The more time wasted, the greater the potential for losing money (a very valuable thing). This habit of coming on time is done repeatedly until it settles automatically in the minds of the students. Activities like this should be done because the potential for students' discipline will be even greater when the habituation to 
come on time is done (Ihsani, Kurniah, \& Suprapti, 2018). The seventh is the habituation of a healthy life. There is no doubt that cleanliness is part of faith. As a Muslim, students should familiarize themselves with healthy living by eating lawful (halal) and nutritious food, and not littering. The habit of healthy living is a realization of the value of health and care for the environment as an inseparable part of the core ethical values of Sundanese culture-based character values. The eighth is habituation of charity and giving alms (shadaqah). Islam teaches people to always have an attitude of generosity. One implementation of someone's generosities is to ask for charity. It aims to realize the attitude of social sensitivity, tolerance, and the practice of an attitude of thanksgiving for the blessing in students. The habit of giving alms also is a process to grow the philanthropic value of students in educational institutions (Suherman, 2019). A research states that students who are in their teens are less sensitive to the surrounding environment, especially environments that need someone's help (Nofiaturrahmah, 2018). Therefore, the inculcation (instilling) of these character values must be done through daily habituation of giving alms and charity. What schools can do is to create a program of caring for others to raise funds, not only from students, but also teaching and education staff must set an example for the realization of this activity. The funds collected are then distributed to people in need by involving the students' council. The ninth is visiting friends who are sick. Activities like this are usually carried out by bringing food as a form of social care to make a moral contribution to those who are sick. So that this habituation of visiting sick students can also be combined with the habituation of charity and giving alms. The tenth is cleaning up the school environment. The inculcation of the value of cleanliness in the school environment must be accompanied by examples, commands, motivations, advice, punishments, and appreciations from the teacher as an educator (Shalihah \& Salamah, 2017). So that students can always follow and practice the same thing. Written rules regarding the obligation to clean and maintain the school environment without being given a real example is an impossibility, because the process of command/invitation (dakwah) which is accompanied by giving examples will be more effective than command/invitation that is only by words alone.

In the end, the current curriculum is not necessary to be accepted and implemented as it is, but the curriculum needs to be developed in the form of innovation following the needs. That is also done as long as the curriculum innovation does not deviate from the main points of the national curriculum (Prastyawan, 2011). The implementation of Islamic education curriculum based on Sundanese character values cannot be separated from the participation of school stakeholders. So that there is a need for good communication between stakeholders in the school, such as school principals, teachers, employees, school committees, and parents or guardians of students (Muslimin, 2016).

The implications of this research can be applied scientifically and practically. In the scientific world, this research can be used as a reference in the development and innovation of the Islamic education curriculum. In the 
practical realm, the implementation of this research can be used as part of the educational institutions' efforts to be able to integrate Sundanese cultural character values with Islamic values in Islamic education to produce students who uphold religion and culture in Indonesia.

\section{CONCLUSIONS}

The presence of Islamic education curriculum innovations based on cultural sundanese character values can provide scientific contributions to achieve national education goals. Innovations that can be done are 10 learning and habituation done by students, namely reading the Surah Yasin once a week, speaking good words, performing Dluha and Dzuhur prayer in congregation, civilizing smile and greetings, praying before and after studying, habituation comes on time, habituation of healthy living, visiting sick friends, and cleaning up the school environment. These innovations are expected to produce the next generation of the nation who not only upholds their religion, but also the culture of ancestors and the Indonesian people.

\section{ACKNOWLEDGEMENTS}

The authors say thanks to the Iqra' Journal: Education Studies that have provided the opportunity to publish this small paper. The authors also thank Prof. Dr. Agus Salim Mansyur, M.Pd. and Dr. Qiqi Yuliati Zaqiah who has provided guidance and suggestion so that this manuscript can be completed.

\section{AUTHOR CONTRIBUTION STATEMENTS}

The author had participated in the research and approved the final version of the manuscript

\section{REFERENCES}

Akhwan, M. (2014). Pendidikan karakter: konsep dan implementasinya dalam pembelajaran di Sekolah/Madrasah. El Tarbawi,8(1), 61-67.. https://doi.org/10.20885/tarbawi.vol7.iss1.art6.

Akwen, G. T., Moorthy, R., \& Daud, S. (2020). The Impact of Fourth Industrial Revolution Era On Nigeria's Counterterrorism Strategy Towards Boko Haram Movement. Jebat: Malaysian Journal of History, Politics E Strategic Studies, 47(1). Google Scholar

Ari Pratiwi, I. (2020). Pembiasaan Budaya 5S (Senyum, Sapa, Salam, Sopan, Santun) Untuk Menumbuhkan Nilai Karakter Dan Budi Pekerti Siswa. Google Scholar.

Asriati, N. (2012). Mengembangkan Karakter Peserta Didik Berbasis Kearifan Lokal Melalui Pembelajaran di Sekolah. Jurnal Pendidikan Sosiologi dan Humaniora, 3(2).. Google Scholar.

Asikin, Z. (2019). Legal Education in Indonesia Towards an Industrial Revolution 4.0. International Journal of Multicultural and Multireligious Understanding, 6(4), 377-384. http:/ / dx.doi.org/10.18415/ijmmu.v6i4.994 
Creswell, J. W. (2016). Research design: pendekatan metode kualitatif, kuantitatif, dan campuran. Yogyakarta: Pustaka Pelajar. Google Scholar

Dalmeri, D. (2014). Pendidikan Untuk Pengembangan Karakter (Telaah terhadap Gagasan Thomas Lickona dalam Educating For Character). AlUlum, 14(1), 269-288.. Google Scholar.

Davidson, M., Lickona, T., \& Khmelkov, V. (2014). Smart and good schools. Handbook of Moral and Character Education, 290.. Google Scholar.

Fajrussalam, H., \& Hasanah, A. (2018). Core Ethical Values of Character Education Based on Sundanese Culture Value. IJECA (International Journal of Education and Curriculum Application), 1(3), 15-22. https://doi.org/10.31764/ijeca.v1i3.2126.

Habibah, S. (2015). Akhlak Dan Etika Dalam Islam. Jurnal Pesona Dasar, 1(4). Google Scholar.

Hadi, S. (2015). Inovasi Kurikulum Keagamaan Di SMAN 1 Pamekasan. TADRIS: Jurnal Pendidikan Islam, 10(1), 119-152.. http://dx.doi.org/10.19105/jpi.v10i1.642. .

Harahap, K. A. H. (2018). Inovasi Pembelajaran Pendidikan Agama Islam (Pai) Di Sekolah Dasar Negeri 097523 Perumnas Batu Vi Kecamatan Siantar Kabupaten Simalungun (Doctoral dissertation, Universitas Islam Negeri Sumatera Utara Medan).. Google Scholar.

Ida, R. (2014). Metode penelitian: Studi media dan kajian budaya. Kencana.. Google Scholar.

Ihsani, N., Kurniah, N., \& Suprapti, A. (2018). Hubungan metode pembiasaan dalam pembelajaran dengan disiplin anak usia dini. Jurnal Ilmiah Potensia, 3(2), 105-110.. https:/ / dx.doi.org/10.33369/jip.3.2.105-110.

Indrawardana, I. (2012). Kearifan lokal adat masyarakat Sunda dalam hubungan dengan lingkungan alam. Komunitas: International Journal of Indonesian Society And Culture, 4(1). https://doi.org/10.15294/komunitas.v4i1.2390.

Irsad, M. (2016). Pengembangan Kurikulum Pendidikan Agama Islam Di Madrasah (Studi Atas Pemikiran Muhaimin. Jurnal Iqra': Kajian Ilmu Pendidikan, 1(2), 230-245. Google Scholar.

Istiawati, N. F. (2016). Pendidikan Karakter Berbasis Nilai-Nilai Kearifan Lokal Adat Ammatoa dalam Menumbuhkan Karakter Konservasi. CENDEKIA: Journal of Education and Teaching, 10(1), 1-18. https:// doi.org/10.30957/cendekia.v10i1.78.

Jeynes, W. H. (2019). A meta-analysis on the relationship between character education and student achievement and behavioral outcomes. Education and Urban Society, 51(1), 33-71.. https://doi.org/10.1177\%2F0013124517747681.

Kaminski, J. (2011). Diffusion of innovation theory. Canadian Journal of Nursing Informatics, 6(2), 1-6.. Google Scholar.

Kominfo. (2020, January 8). Siaran Pers No. 04/HM/KOMINFO/01/2020 Rabu, 08 Januari 2020 Tentang Kominfo Terima Lebih Dari 430 Ribu Aduan Konten Negatif Sepanjang 2019. Google Scholar. 
Lestari, M. (2019, Agustus). Jabar Saber Hoaks Klarifikasi 2.643 Berita Bohong di Medsos. Detiknews.

Mahmud, H. (2013). Guru Di Tengah Perubahan Kurikulum. Al-Khwarizmi: Jurnal Pendidikan Matematika dan Ilmu Pengetahuan Alam, 1(2), 111-124.. Google Scholar.

Mansyur, A. S. (2017). Pengembangan Kurikulum Berbasis Karakter: Konsepsi Dan Implmentasinya. Jurnal Pendidikan UNIGA, 1(1), 1-9. Google Scholar.

Marshall, J. C., Caldwell, S. D., \& Foster, J. (2011). Moral education the CHARACTER plus Way®. Journal of Moral Education, 40(1), 51-72. https://doi.org/10.1080/03057240.2011.541770.

Maria, M., Shahbodin, F., \& Pee, N. C. (2018, September). Malaysian higher education system towards industry 4.0-current trends overview. In AIP Conference Proceedings (Vol. 2016, No. 1, p. 020081). AIP Publishing LLC. https://doi.org/10.1063/1.5055483

Maryanti, N., Rohana, R., \& Kristiawan, M. (2020). The Principal's Strategy In Preparing Students Ready To Face the Industrial Revolution 4.0. International Journal of Educational Review, 2(1), 54-69. https://doi.org/10.33369/ijer.v2i1.10628

Jamal, J., \& Astuti, B. (2020, February). The Effect of Symbolic Modeling Techniques Through Video Shows to Reduce Bullying Behavior of Students in Industrial Revolution 4.0. In 3rd International Conference on Learning Innovation and Quality Education (ICLIQE 2019) (pp. 354-360). Atlantis Press. https:/ / doi.org/10.2991/assehr.k.200129.045

Moser, A., \& Korstjens, I. (2018). Series: Practical guidance to qualitative research. Part 3: Sampling, data collection and analysis. European Journal of General Practice, 24(1), 9-18. https://doi.org/10.1080/13814788.2017.1375091

Muslimin, N. (2016). Inovasi Kurikulum dalam Upaya Meningkatkan Mutu Pendidikan. Ta'allum: Jurnal Pendidikan Islam, 4(1), 43-61. http://dx.doi.org/10.21274/taalum.2016.4.1.43-61.

Nofiaturrahmah, F. (2018). Penanaman Karakter Dermawan Melalui Sedekah. ZISWAF: Jurnal Zakat dan Wakaf, 4(2), 313-326. http:// dx.doi.org/10.21043/ ziswaf.v4i2.

Nucci, L., \& Narváez, D. (Eds.). (2014). Handbook of moral and character education. Routledge. Google Scholar.

O'Dwyer, L. M., \& Bernauer, J. A. (2013). Quantitative Research for the Qualitative Researcher. SAGE Publications. Google Scholar

Prastyawan. (2011). Inovasi Kurikulum Dan Pembelajaran. Al-Hikmah: Jurnal Studi Keislaman, 1(2), 170-181. https:/ / doi.org/10.36835/hjsk.v1i2.347.

Pratikno, A. S. (2016). Pendidikan Karakter Religius Melalui Pembiasaan Membaca Surat Yasin Secara Klasikal. Seminar Nasional Pendidikan Karakter, 55-64. Google Scholar.

Pusparisa, Y. (2020, January 23). Pornografi Dominasi Konten Aduan Sepanjang 2019. Retrieved April 28, 2020, from Databoks website: 
https:/ / databoks.katadata.co.id/ datapublish/2020/01/23/pornografidominasi-konten-aduan-sepanjang-2019\#.

Putra, A. B. N. R., Mukhadis, A., Soraya, D. U., Dzakiya, N., Pratama, M. M. A., \& Nidhom, A. M. (2019, January). The Innovation of Hybrid Learning through Live 24-Hour Streaming Personal in the Learning Process in Higher Education of Vocational in the Era of Industrial Revolution 4.0. In 2nd International Conference on Vocational Education and Training (ICOVET 2018). Atlantis Press. https://doi.org/10.2991/icovet-18.2019.64

Rahmi, Y. (2016). Budaya Kerja Islami Guru-Guru SDN Kota Solok dalam Meningkatkan Mutu Hasil Belajar. Al-Fikrah: Jurnal Manajemen Pendidikan, 2(2), 187-200. http://dx.doi.org/10.31958/jaf.v2i2.384.

Rasyidi, M. (2019). INOVASI KURIKULUM DI MADRASAH ALIYAH. Al Qalam: Jurnal Ilmiah Keagamaan dan Kemasyarakatan, 33-50. http://dx.doi.org/10.35931/aq.v0i0.106.

Setiawan, A. (2019). Implementation of Islamic Education Study Program Learning Based on Blended Learning in the Industrial Era 4.0 at IAIN Samarinda. Dinamika Ilmu, 19(2), 305-321.

Shalihah, S., \& Salamah, S. (2017). Penanaman Nilai-Nilai Kebersihan Lingkungan oleh Guru Di MI Hayatuddiniah Jambu Burung Kecamatan Beruntung Baru Kabupaten Banjar. Al-Adzka: Jurnal Ilmiah Pendidikan Guru Madrasah Ibtidaiyah, 7(1), 145-166. https://dx.doi.org/10.18592/aladzkapgmi.v7i1.2026. .

Sugiana, A. (2019). Pengembangan Kurikulum Pendidikan Agama Islam dan Implementasinya di MTs Nurul Ummah Yogyakarta. Jurnal Pendidikan Agama Islam, 16(1), 17-34. https://doi.org/10.14421/jpai.jpai.2019.16102.

Suherman. (2019). Penanaman Nilai Filantropi Islam di Lembaga Pendidikan (Studi Kasus SDI Surya Buana Kota Malang). AL-ASASIYYA: Journal Of Basic Education, 3(2), 140-151. http://dx.doi.org/10.24269/ajbe.v3i2.1824.

Sulasmono, P., Ekosiswoyo, R., \& Widodo, J. (2010). The Integration of Local Cultural Wisdom Values in Building The Character Education of Students. Education, 36. Google Scholar.

Sulhan, M. (2018). Pendidikan Karakter Berbasis Budaya dalam Menghadapi Tantangan Globalisasi. Jurnal Visipena, 9(1), 159-172. https://doi.org/10.46244/visipena.v9i1.450.

Zubaedi, M. A. (2015). Desain Pendidikan Karakter. Prenada Media. Google Scholar. 


\section{Copyright Holder :}

(c) Fajrussalam, H., Mansyur, A., \& Zaqiah, Q. (2020)

First Publication Right :

(C) Jurnal Iqra' : Kajian Ilmu Pendidikan

This article is under:

(1) (1) (2) 